\section{THE DIAGNOSIS AND TREATMENT OF} INTRATHORACIC GROWTHS

By Maurice Davidson, M.A., D.M., B.Ch., F.R.C.P., David W. SMithers, M.D., M.R.C.P., D.M.R., and Oswald S. TubBS, M.A., M.B., B.Chir., F.R.C.S. Pp. vii +260 , with 170 illustrations. London: Geoffrey Cumberlege, Oxford University Press. I 95 I. $42 s$.

This book consists of a detailed account, mainly from the clinical and radiological points of view, of intrathoracic tumours, written in the clear, cultured style to which Dr. Davidson's previous publications have accustomed us. Professor Smithers contributes a valuable account of the methods of palliative, and attempted radical X-ray treatment of intrathoracic neoplasms used at the Royal Cancer Hospital, together with an analysis of the results of such treatment in carcinoma of the bronchus seen at the joint consultation clinic of the Brompton Hospital and the Royal Cancer Hospital. Mr. Tubbs adds a succinct and informative account of the surgical treatment of both benign and malignant intrathoracic tumours.

The book, built on a wealth of clinical material, gives a thorough and entirely readable account of the whole subject. It is beautifully produced and liberally illustrated, the standard of illustration being high. From the point of view of future editions, the reviewer is personally inclined to doubt the value of line drawings in illustrations of radiographic appearances, to note certain errors in nomenclature in the diagrams of the bronchial tree and to miss reference to recent work on the possible role of smoking in the aetiology of carcinoma of the bronchus. This he does to fulfil his duty, not in any way to detract from the value of the book.

Many of Dr. Davidson's colleagues will be proud to have this book on their shelves and to refer to it for his rich experience. To others not known to him, in further fields, it will convey much of the best in British medicine.

\section{PROSTITUTION AND THE LAW}

By T. E. James, M.A., B.C.L., Barrister-at-Law. Pp. $1 x+160$. London: William Heinemann. I 95 I. 2 Is.

Though Mr. James sets out to discuss the law relating to prostitution, he very properly recognizes that there is little profit in doing so exclusively. Prostitution is chiefly a social and moral problem, its legal aspect being almost in the nature of a byproduct, for no amount of legislation will improve morals. The author has therefore been obliged also to sketch its relation, historical and actual, to social, moral and economic factors. That he has succeeded in doing so effectively and also in providing an almost exhaustive summary of the English law on the subject, with an adequate guide to the essence of the legislation of the United States, France and the Soviet Union, is a remarkable feat of condensation. It would in fact be difficult to indicate a superfluous word in the whole book
There seems to be general consensus of opinio that prostitution cannot be prevented by law, and that the utmost the law can do is to regulate it, kee it within bounds and prevent some of its worse effects. The English legislature and bench seem to have recognized this fact and never to have: attempted serious systematization, with the resuff that our law of prostitution is a chaos which only specialist like Mr. James can know really well, an which when known turns out to belong to a pass age and culture. This, he explains, has not mattere very much so long as the police have kept publio order with their usual sensitive regard for publie opinion. Nevertheless, he is far from satisfied with such a state of affairs, and points to the modern techniques by which ideals are injected into society్ and behaviour moulded. These methods have beeng mostly misused for political ends, but there is $Q$ wide field for their constructive application. He. believes that prostitution as an emotional problenfi could as a rule be dealt with in the family if propeto advice and help were provided sufficiently early $\vec{N}$ and suggests that this might be done through 2 legally-constituted tribunal. He devotes some space to an illuminating account of the operation of the Philadelphia Municipal Court, with its divisions for juveniles, misdemeanants and domestic relations its staff of physicians and psychologists, and it statistical department. He also speaks, with con siderable scepticism but with close objective atten tion, of the position in the Soviet Union so farogef he is able to know it. While the Russian Govenn ment continue to combine extravagant claims their social order with extravagant means for pies venting anyone from examining it, their statement that they have abolished prostitution must continu to be taken with great reserve. They may have removed some of the economic causes but not, in Mr. James's opinion, the emotional causes of the evil.

Mr. James concludes that little good would be achieved by merely amending our law. The energ expended would be much better applied at the rootsof the problem, unless the indeterminate sentence and professionally-trained personnel could be intro $\overline{-}$. duced. Scientific research should be conductes into the emotional causes in both the male and the female partners. For the female, recognisanceso imprisonment and the 40s. fine are no more than stopgaps as at present used. Informal enquiry int $Q$ personal problems would help either directly os by gradually undermining the woman's interest prostitution. Rehabilitation after venereal disease. should be perfected. Economic conditions of women should be improved, and the principle of equal pay for equal work should be applied ip practice. He has produced a most valuable introw duction to this perplexing field for the researct worker and the would-be reformer, for he has appended full bibliographies to each of his chapters so that practically every point he makes can bழt followed up in the literature. His index is not very full, but this defect is compensated for is part by the crisp subdivision of the book. 